\title{
THE USE OF TRANSGLUTAMINASE ENZYME IN PROCESSING RAS CHEESE \\ Metwally,A.M.M. ${ }^{1}$;Sanna M.Badran ${ }^{1}$;E. A.Emara ${ }^{2}$ and Hend H.E. Ali ${ }^{2}$ \\ ${ }^{1}$ Dairy Science and Technology Department, Faculty of Agriculture, Cairo University, Giza, Egypt \\ ${ }^{2}$ Dairy Technology Department, Animals Production Research Institute, Agriculture research center, Egypt
}

\begin{abstract}
To overcome the problem of the delayed ripening of ripened cheeses made with Transglutaminase enzyme, a number of starters were selected for their proteolysis activity. Ras cheese slurry was made using the selected cultures, incubated at $30 \mathrm{C}$ for 30 days and was chemically and organoleptically tested.Two cultures combinations resulted of good quality slurry. L. Helveticus and L. Lactis, and $L$. helveticus, $L$. lactis and $L$. casei resulted in good Ras cheese slurry, particularly the former one.

Keyword: Transglutaminase, Lactic Acid Bacteria, Ras Cheese, Ripened Cheese
\end{abstract}

\section{INTRODUCTION}

Transglutaminase enzyme is used in production of different dairy products since it improves the yield as well as the body and structure of the product particularly low fat products. In yogurt, the enzyme increased gel strength and decreased syneresis particularly in low fat yogurt,(Iuliana et al., 2012).In soft cheese, the enzyme gave higher gel firmness, increased the yield, decreased syneresis and improved organoleptic properties,(leva, 2013). In low fat mozzarella cheese, the enzyme increased cheese yield by increasing moisture, fat and protein recovery. The enzyme improved stretchability and meltability as well asorganoleptic properties (Metwallyet al., 2007). In low fat ice cream, the enzyme compensated for the low fat to produce a product superior in all physical and organoleptic properties than control (Metwally, 2007, Priscillaet al., 2012).

However, the use of the enzyme in ripened cheese was limited due to the delayed ripening process resulting from slow microbial proteolytic activity leading to a harder texture and low meltability (Özer, 2007). This is a result of the enzyme cross-linking reaction which reduces the availability of low molecular weight peptides used as nitrogen source by the starter (Fæaergemand, 1999).

Aaltonen et al (2014) used the enzyme for making Edam cheese from ultrafiltrated milk. Ultrafiltration of milk was used to remove the enzyme inhibitor present in milk. The enzyme was incubated with the retentate at $17 \square \mathrm{C}$ for $2 \mathrm{~h}$, then the mix was standardized with raw milk which containing the inhibitor. The resulted cheese was harder in texture than the control. Therefore, they suggested the use of peptidase to overcome the low free amino acids present in UF cheese (Aaltonen and Huumonen 2013). 
To overcome the slow activity of ripening culture in Transglutaminase (TG) cheese, this research tried to select culture strains that can be active and help in normal ripening of the cheese.

\section{MATERIALS AND METHODS}

\section{Materials:}

Starter cultures of Lactobacillushelveticus $\left(1654^{\mathrm{T}}\right.$, Lactobacillus caseisubspcasei $\left(1093^{\top}\right)$, Lactobacillus delbreuckii bulgaricus (761N), Lactococcuslactissubsplactis(1106)andStreptococcus salivarius subsp. thermophilus(1043)were obtained from Microbiological Resources Center, Cairo MIRCEN, College of Agriculture, Ain Shams University.

Cow milk was obtained from Dairy Department pilot plant, College of Agriculture, Cairo University.

A microbial Transglutaminase (EC: 2.3.2.13) obtained from streptoverticillum mobaraense, commercially available as (ACTIVA® YG) was used. The enzyme (declared activity is $100 \mathrm{U} / \mathrm{g}$ ) was a gift from Ajinomoto Europe Sales Gmbh, Hamburg Germany.

\section{Methods}

Chemicals used were of high purity.

\section{Selecting the proper culture:}

Activated culture strains, single or in combinations with ratio 1:1, were tested for their proteolytic activity using the method of Church et al., 1983.One percent,either ofa single or in $1: 1$ combination of microorganisms, of the active culture was inoculated into $100 \mathrm{ml}$ of sterile skim milk, incubated for $24 \mathrm{~h}$ at $37 \square \mathrm{C}$.

Combinations of the strains were selected for their high proteolytic activity and were used in making cheese slurry.

\section{Milk rennet coagulation using the TG enzyme:}

Milk was coagulated with rennet in presence of TG following the method of Metwally et al (2007).

\section{Ras Cheese Slurry Making:}

Cheese slurry was made according to the normal Ras cheese manufacturing protocol followed the procedure of Abdelfattah 1998. Fresh cow's milk was pasteurized at $72^{\circ} \mathrm{C} / 15 \mathrm{~s}$, and inoculated with $2 \%$ starter of the selected combination. Milk was kept for $30 \mathrm{~min}$ for development of the proper acidity $(0.18 \%)$ then cooled down to $5^{\circ} \mathrm{C}$. Liquid rennet was added tomilkat a rate of $2.5 \mathrm{ml} / \mathrm{kg}$ and left for $30 \mathrm{~min}$ at $5{ }^{\circ} \mathrm{C}$. Then $0.05 \%$ of Transglutaminase was addedand the mixture was left for $2 \mathrm{~h}$ at $5{ }^{\circ} \mathrm{C}$ before raising the temperature to $40^{\circ} \mathrm{C}$ to complete coagulation. The curd was cut vertically and horizontally with sterilized knives and the temperature was raised to $45^{\circ} \mathrm{C}$ within $15 \mathrm{~min}$. When the curd particles reached the grain size, they were allowed to settle down in the bottom of the cheese vat. Half of the whey was drained off using a sterilized cheesecloth, and then salt was added at rat of $20 \mathrm{~g}$ per $\mathrm{kg}$ of milk. Mixingcontinued for $10 \mathrm{~min}$, and then the remaining whey was drained off completely usingcheesecloth. The curd was then filled into a sterilized glass jars and covered with sterilized screw plastic cap. The jars 
were completely filled with curd leaving no air space. Empty glass jars and their caps were sterilized by boilingin water for $20 \mathrm{~min}$ before use. Control cheese was made following the same procedure without TG enzyme.

The slurry was incubated at $30^{\circ} \mathrm{C}$ for 30 days and their chemical and organoleptic properties were tested.

\section{Slurry Chemical Tests:}

Slurry Total Protein andSoluble Nitrogen was determined by semimicro Kjeldahl method according to SMEDP (1985), acidity by the method of Ling (1963), fat by the Gerber method, sodium chloride by the method of IDF (1982) and total volatile acids by the methods of Kosikowski (1978).

Organoleptic Properties:

Cheese slurry was judged by number of the Department staff members, and the average of their score was reported.

\section{Statistical Analysis:}

All measurements were done in triplicate then reported as the arithmetic mean. Analysis of variance (one way Anova) was used for multiple comparisons over the different treatments. The statistical significance of the data was determined using Fisher's LSD post hoc test. P-value $\square 0.05$ was considered sufficient to reject the null hypothesis. Statistical analysis was performed by running the SPSS 20 (IBM Corp., Copyright@ 2011) package on a personal computer.

\section{RESULTS AND DISCUSSIONS}

The problem of using TG enzyme in ripened cheese is the slow and incomplete ripening due to low starter activity. Thiswas attributed to the lack of small peptides that can be used as nitrogen source for their activity. Thisresearch was carried out to select cultures that can grow in TG cheese overcoming the above problem through their proteolytic activity.

Cheese slurry was used to screen microorganisms for their growth and effect on cheese ripening. Because of the lengthy ripening time required for flavor development, evaluation of each strain on quality is time consuming and costly. Therefore, cheese slurry is used to rapidly evaluate flavor and proteolytic potential of the starter in an efficient way.

Five strains of microorganisms, grouped in seven different combinations, were grown in sterile skim milk, and their proteolytic activities were determined and results are presented in Table (1).

The mixture of $L$. casei and $L$. lactis produced more proteolysis than other combinations followed by $L$. helveticus and L. lactis. Therefore, both combinations were used as starter for processing Ras cheese slurry. 
Table (1): Proteolytic activity of combination of strains of lactic acid bacteria

\begin{tabular}{|l|c|}
\hline Strains $^{123}$ & $\begin{array}{c}\text { Absorbance } \\
\text { at } 340 \mathrm{~nm}\end{array}$ \\
\hline L. helveticus and L. casei & 0.591 \\
\hline L. helveticus and L. bulgaricus & 0.639 \\
\hline L. helveticus and S. thermophilus & 0.548 \\
\hline L. helveticus and L. lactis & 0.663 \\
\hline L. casei and S. thermophilus & 0.611 \\
\hline L. casei and L. bulgaricus & 0.546 \\
\hline L. casei and L. lactis & 0.784 \\
\hline
\end{tabular}

1. Ratio of mixing was 1:1

2. Incubation temperature was $30 \square \mathrm{C}$ for $24 \mathrm{~h}$.

3. Inoculation rate was $1 \%$ in sterile skim milk.

The above two starters were formed of $L$. helveticus, $L$. lactis and $L$. caseimicroorganisms. Therefore, the three microorganisms were mixed together to form a third group to find out the effect of mixing on cheese.Streptococcusthermophilus and $L$. bulgaricus starter was used as a control with and without TG enzyme. Table (2) presents Ras cheese slurry chemical composition made with the above three cultures and compared with the control. Lactobacillushelveticus and L. lactis starter resulted in the highest protein, fat, soluble nitrogen (SN) and total volatile fatty acids than other starters. This is followed by the control without the enzyme, since TG enzyme reduced the control protein and $\mathrm{SN}$. The other two groups were almost similar in their chemical composition.

Table(2):Chemical composition of Ras cheese slurry with Transglutaminase enzyme and with different starters

\begin{tabular}{|l|c|c|c|c|c|c|c|c|}
\hline \multirow{2}{*}{ Strains } & \multicolumn{7}{|c|}{ Chemical Composition } \\
\cline { 2 - 8 } & $\begin{array}{c}\text { Total } \\
\text { Protein }\end{array}$ & Fat & Moisture & Salt & $\begin{array}{c}\text { Acidit } \\
\mathbf{y}\end{array}$ & S.N. $^{2}$ & T.V.F.A $^{\mathbf{3}}$ \\
\cline { 2 - 8 } & \multicolumn{7}{|c|}{$\%$} & mg/l \\
\hline Control $^{1}$ & 21.43 & 32 & 44.52 & 1.2 & 2 & $0.64 \mathrm{ace}$ & $4.86 \mathrm{ace}$ \\
\hline L. bulgaricus and S. thermophilus & 20.8 & 34 & 48.38 & 1 & 1.9 & $0.54 \mathrm{~b}$ & $4.64 \mathrm{~b}$ \\
\hline L. casei and L. lactis & 20.72 & 35 & 42.18 & 1.3 & 3.06 & $0.64 \mathrm{ace}$ & $4.86 \mathrm{ace}$ \\
\hline L. helveticus and L. lactis & 23.58 & 35 & 41.94 & 1.5 & 3.25 & $0.72 \mathrm{~d}$ & $5.46 \mathrm{~d}$ \\
\hline $\begin{array}{l}\text { L. helveticus and L. lactis and L. L. } \\
\text { casei }\end{array}$ & 20.54 & 35 & 41.43 & 1.2 & 2.9 & $0.66 \mathrm{ace}$ & $4.88 \mathrm{ace}$ \\
\hline
\end{tabular}

- Incubation temperature was $30 \square$ for 30 days.

- Inoculation rate was $1 \%$ in sterile skim milk.

- Microorganisms were mixed in equal rates.

- Means followed by same letter(s) within each column are not significantly different at $5 \%$ levels of probability

1. The control used was $L$. bulgaricus and $S$. thermophilus without the enzyme

2. Soluble Nitrogen

3. Total volatile fatty acids

The culture with the three microorganisms did not compare well with other two groups. However, to emphasize the above results and to find the effect the Enzyme on the final product, the two cultures, the $L$. helveticusand 
L. Lactis culture, and the L. helveticus and L. lactis and L. casei culture with and without the enzyme were compared and reported in Table (3).Lactobacillus helveticus and L. lactis improved slurry composition made with the enzyme. The enzyme increased the yield, $\mathrm{SN}$ and total volatile fatty acids in the slurry compared to its control.

The other culture did not compare well with the above culture,but still the culture improved the yield, SN over its control.

Table(3):The effect of selected cultures on chemical composition of Ras cheese slurry made with Transglutaminase enzyme.

\begin{tabular}{|c|c|c|c|c|c|c|c|c|}
\hline \multirow{3}{*}{ Culture } & & \multicolumn{7}{|c|}{ Chemical Composition } \\
\hline & Yield & $\begin{array}{c}\text { Total } \\
\text { Protein }\end{array}$ & Fat & Moisture & Salt & Acidity & S.N. ${ }^{1}$ & \multirow{2}{*}{$\begin{array}{c}\begin{array}{c}\text { T.V.F. } \\
\mathbf{A}^{2}\end{array} \\
\mathrm{mg} / \mathrm{l}\end{array}$} \\
\hline & g & \multicolumn{6}{|c|}{$\%$} & \\
\hline L. helveticus and L. lactis(Control) & 401 & 26.61 & 35 & 64.66 & 1 & 2.5 & 0.66 & 5.14 \\
\hline L. helveticus and L. lactis & 406 & 26.97 & 36 & 66.66 & 1 & 3 & 0.92 & 6.24 \\
\hline $\begin{array}{l}\text { L. helveticus and L. lactis and L. } \\
\text { casei(Control) }\end{array}$ & 444 & 21.25 & 28 & 66.66 & 1 & 3.5 & 0.72 & 4.56 \\
\hline $\begin{array}{l}\text { L. helveticus and L. lactis and L. } \\
\text { casei }\end{array}$ & 448 & 22.73 & 29 & 66.66 & 1 & 3.56 & 0.78 & 4.74 \\
\hline
\end{tabular}

- Microorganisms were mixed in equal rates.

- Controls were processed without the enzyme.

1. Soluble Nitrogen

2. Total volatile fatty acids

Table (4) compares slurry sensory evaluation of the five used cultures. Once again, L. helveticus and L. lactis and L. helveticus, L. casei and $L$. lactis, produced best result, in flavor, body and texture, acceptability and in turn total score. The difference from the control was great, whether the control contains the enzyme or not.

Table(4):Sensory evaluation of Ras cheese slurry made with Transglutaminase enzyme and selected cultures.

\begin{tabular}{|c|c|c|c|c|}
\hline \multirow[t]{2}{*}{ Strains } & \multicolumn{4}{|c|}{ Average Score of } \\
\hline & Flavor & $\begin{array}{l}\text { Body \& } \\
\text { Texture }\end{array}$ & Acceptability & $\begin{array}{l}\text { Total } \\
\text { Score }\end{array}$ \\
\hline & (50) & (35) & (15) & (100) \\
\hline $\begin{array}{l}\text { Control } \\
L . \text { bulgaricus and } S \text {. thermophilus } \\
\text { L. casei and } L \text {. lactis } \\
\text { L. helveticus and L. lactis }\end{array}$ & $\begin{array}{l}32.1 \\
32.3 \\
40.8 \\
43.4\end{array}$ & $\begin{array}{l}26.27 \\
22.75 \\
28 \\
28.37\end{array}$ & $\begin{array}{c}9.85 \\
9.85 \\
11.87 \\
12.62\end{array}$ & $\begin{array}{l}68.22 \mathrm{abe} \\
64.90 \mathrm{ae} \\
80.67 \mathrm{bcd} \\
84.39 \mathrm{~cd}\end{array}$ \\
\hline $\begin{array}{l}\text { L. helveticus and } L \text {. lactis and } L \text {. } \\
\text { casei }\end{array}$ & 44.3 & 28 & 12.75 & $85.05 \mathrm{bcd}$ \\
\hline
\end{tabular}

- The control used was $L$. bulgaricus and $S$. thermophilus without the enzyme

- Slurries were incubated at $30 \square C$ for 30 days.

- Number of banalities were ten

- The starters were compared with 1:1 ratio of each microorganism.

- Means followed by same letter(s) within each column are not significantly different at $5 \%$ levels of probability 
Cultures used improved the organoleptic properties of the slurry as compared to the control which is usually used for making Ras cheese. The use of the enzyme with the control did not improve the cheese but was less acceptable than the control without the enzyme.

To be sure of this good performance of both cultures, another batch of slurry was made using both cultures, with and without the enzyme and the sensory evaluation are shown in Table (5).

Table (5): Effect of selected cultures on the sensory evaluation of cheese slurry made with Transglutaminase enzyme.

\begin{tabular}{|c|c|c|c|c|}
\hline \multirow[t]{2}{*}{ Strains } & \multicolumn{4}{|c|}{ Average Score of } \\
\hline & Flavor & $\begin{array}{l}\text { Body \& } \\
\text { Texture }\end{array}$ & $\begin{array}{l}\text { Acceptabil } \\
\text { ity }\end{array}$ & $\begin{array}{l}\text { Total } \\
\text { Score }\end{array}$ \\
\hline & (50) & (35) & (15) & $(100)$ \\
\hline L. helveticus and L. lactis(Control) & 42.75 & 29.00 & 11.5 & 83.25 \\
\hline L. helveticus and L. lactis & 45.75 & 31.00 & 13.0 & 89.75 \\
\hline $\begin{array}{l}\text { L. helveticus and } L \text {. lactis and } L \text {. } \\
\text { casei(Control) }\end{array}$ & 37.75 & 24.25 & 9.75 & 71.75 \\
\hline L. helveticus and L. lactis and L. casei & 39.25 & 25.75 & 9.00 & 74.00 \\
\hline
\end{tabular}

- Slurries were incubated at $30 \square C$ for 30 days.

- Number of banalities were ten

- The starters were compared with equal ratio of each microorganism.

Both cultures produced slurry with good acceptability, particularly $L$. helveticus and $L$. lactis culture, and the product matches Ras cheese flavor. The other culture also produced slurry with good acceptability as compared to the control reported in Table (4).

Therefore, the selected cultures used in this research, which had some proteolytic activity, solved the problem of using the TG enzyme in processing ripened cheese.

Other types of ripened chesses mayuse this procedure to select their proper starter that solve the problem of using the TG enzyme.

\section{REFERENCES}

Iuliana, A., Cerasela, E. M., and Iuliana, B. (2012). Effect of Transglutaminase Treatment on Skimmed Yogurt Properties. Food Technology, 36. (2) 20-30.

leva, M., Christopher, G., Daiva, L., and Ulrich, K. (2013). Influence of Transglutaminase on the Physical and Chemical Properties of Acid Milk Gel and Cottage Type Cheese. Journal of Food, Agriculture \& Environment, 11 (3\& 4) $119-124$.

Priscilla, N. R., Vívian, M. B., Marilde, T.and Bordignon-Luiz. (2012). Effect of microbial Transglutaminase on functional and rheological properties of ice cream with different fat contents. Food Science and Technology, $48,224-230$. 
Abdelfattah, A. E. (1998). Processed Cheese Technology as Affecting Quality. M.Sc. Thesis. Dairy Department, Faculty of Agriculture, Cairo University, Egypt.

Church, C. F.; Swaisgood, H. E.; Porter, D. H. and Catignai, G. L. (1983). Spectrophotometric Assay Using O-Phthaldehyde for the Determination of Proteolysis in Milk and Isolated milk Proteins.J.Dairy Sci.66:12191227.

Aaltonen, T; Huumonen J. and Myllarinen (2014) Controlled TransglutaminaseTreatment in Edam Cheese-making. International Dairy J. 38, $179-182$.

Aaltonen, T and Huumonen J. (2013). Ripening Of Cheese Made From Full Concentrated Milk Retentate with and Without Peptidase Addition. International Journal of Dairy Technology. 66, 214 - 219.

Metwally M. M. E.; El-zeini; Zedan, M. A. and Gazar E. F. (2007). Utilization of Transglutaminaze in Mozzerella Cheese Manufacturing. J. Agric. Sci. Mansura Univ. 32, 7, 5151- 5167.

Metwally, A. M. M. E. (2007). Effect of Enzymatic Cross-Linking Of Milk Proteins on Properties of Ice Cream with Different Composition. International Journal of Food Science and Technology. 42, 939-947.

Özer, B., Kirmaci, H.A., Öztekin, S., Hayaloglu, A., Atamer, M. (2007). Incorporation of microbial Transglutaminase into non-fat yoghurt production, International Dairy Journal. 17, 199-207.

Fæaergemand, M., Sorensen, M.V., Jorgensen, U., Budolfsen, G., Qvist, K.B. (1999). Transglutaminase effect on instrumental and sensory texture of set style yoghurt, Milchwissenschaft. 54, 10, 563-566.

Ling, E..R. (1963). A. Textbook of Dairy Chemistry (Practical third ed.) Chapman and Hall, London, U.K. (1963) (vol. 2).

Kosikowski F.V. (1978). Cheese and fermented milk foods. Second ed. Cornell Univ., Inthacu; New York, U.S.A: 1978.

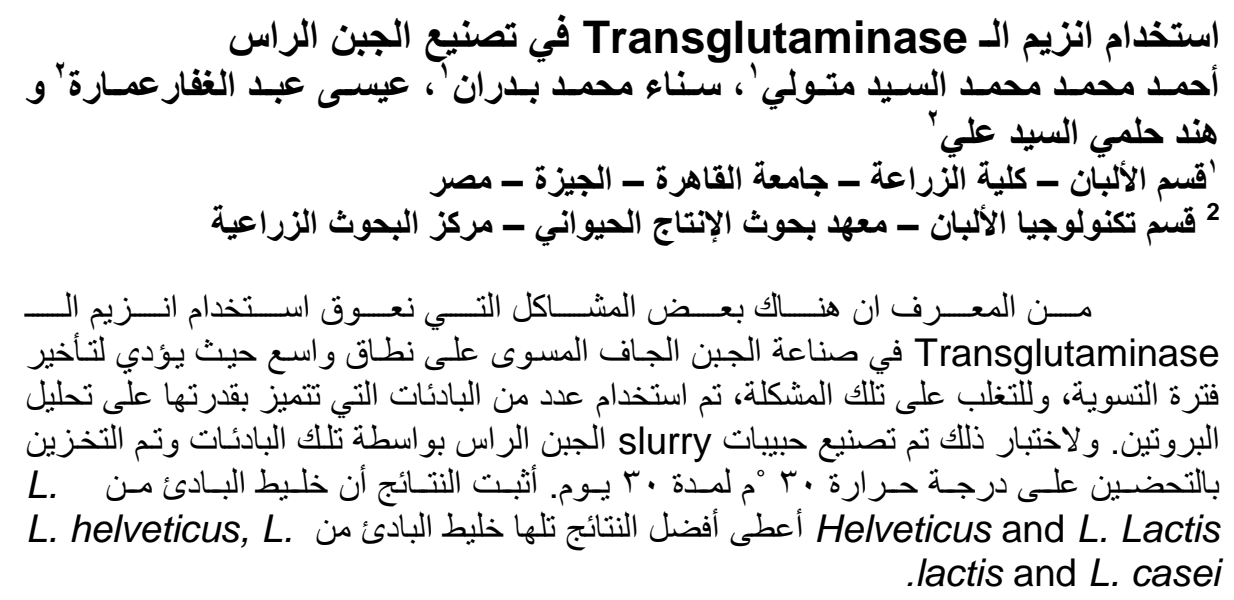

